helpful in laying out important issues. But if ELSI projects are to enhance public understanding and influence social policy, this is no longer enough. We need more concrete data addressing the institutional, political and cultural context in which genetic information will be used and abused. Historical lessons, philosophical inquiries, scientific wisdom will have greater impact if we understand the contemporary contexts in which science is applied. By now, empirical investigations should be testing theoretical speculations, and scholarly explorations should be reflected in public education. More recent ELSI projects are directed to these ends and should soon be reflected in scholarly writing on the subject.

Dorothy Nelkin is in the Department of Sociology, 269 Mercer Street, New York University, New York, New York 10003, USA.

\section{Sex and the singular woman}

\section{Richard Davenport-Hines}

Marie Stopes and the Sexual Revolution. By June Rose. Faber and Faber: 1992. Pp. 272. £14.99, \$22.95.

MARIE Stopes is best remembered as the brave and generous woman who in 1921 opened Britain's first birth-control clinic, staffed by women and providing free advice. She was also a doughty sexual publicist whose manual Married Love (1918) "came crashing into English society like a bombshell", as its author described, with an "explosively contagious" denunciation of the habit "of using the woman as the passive instrument of man's need".

Born in 1880 , she was a brilliant oddity: her father was an ardent amateur palaeontologist who stimulated her interest in science; her mother drove her into a formidable if unamiable precocity. By the age of 17 she had read all of Darwin, Kant and Swedenborg. She took science degrees at London and Munich universities and in 1905 became the youngest ever Doctor of Science. During the following year, despite being penniless, she took herself on an intrepid botanizing tour of Japan. She applied to join Scott on his Antarctic expedition, and was outraged to be rejected on the grounds of her sex. At considerable emotional cost, which she hid from herself, she attended meetings of scientific societies which were misogynistic and even contemptuous.

The course of her life was changed by the failure of her first marriage. Full of sexual yearnings but confused by romantic ideals, she married in 1911, but obtained an annulment in 1916 on grounds of nonconsummation (although June Rose suggests that Stopes's complaints of her first husband's impotence were untrue). Camping alone on a windswept beach at this time, she compiled a "Tabulation of Symptoms of Sexual Excitement in Solitude". It was in this stato of sexual frustration and resentment, claiming still to be an unhappy virgin, that she wrote the book that made her name, Married Love.

For hundreds of years there had been sexual manuals written for men. This was the first such book written by a woman for other women describing foreplay, sexual techniques and orgasm. "In it she dared to stake a claim for female sexuality", as Rose writes. "Her views

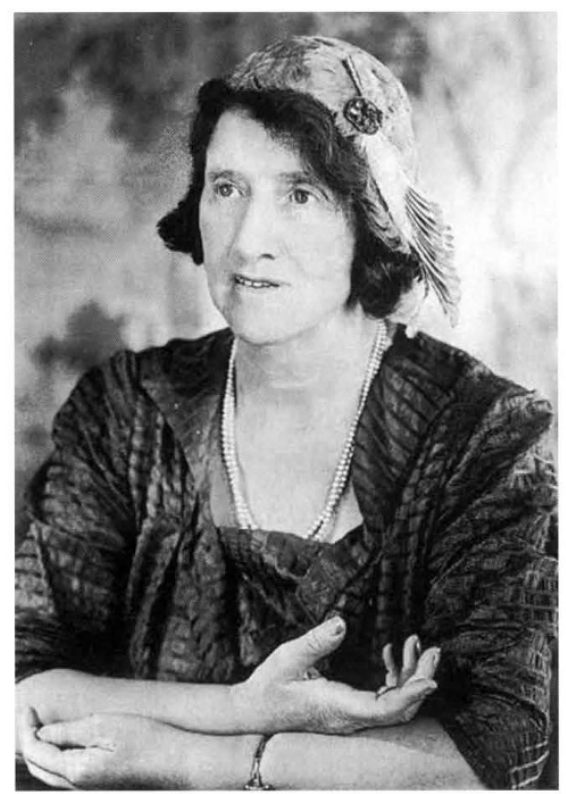

The lovers' guide. Stopes in fact emerges as a magnificent monster.

challenged centuries of prejudice and superstition and the accretions of religious teaching which saw women's bodies and women's attractions as desirable but also dirty." She wrote with an intensity of feeling to which other women responded, although the quaintness of some of her phrases can seem absurd today.

Thereafter she became increasingly sex-obsessed. She was a prolific writer and vivid controversialist whose campaigns involved her in lawsuits, ostracism and public abuse. She never shirked what she saw as her duty, and never spared herself. Her private life was turbulent. She married again in 1918, and was inconsolable when her first child was stillborn. In 1924 a second son was born. At home (as in many of her public dealings) Stopes was tactless, humourless, cruel and headstrong, a crashing snob and driving bully who made an arid waste of the lives of several of the people nearest to her. She was closer to her vicious chow-chow Wuffles than to her immediate family.

June Rose writes in a tone that mixes admiration with irony. There is much to admire in the life of this energetic and daunting woman. The letters to Stopes from ill, exhausted women of the slums asking for contraceptive advice, or thanking her for her work, are exceedingly moving documents. But like other early popularizers of contraceptive education, she was interested in eugenics and developed a propagandist zeal for racial purity that seems ugly to later generations. Her lack of humour and her tunnel vision understandably antagonized medical opinion and should have served as a warning to sex educators ever since.

Stopes was sensitive to her status as a scientist, yet her contacts with the scientific community are slightly neglected. She suffered (perhaps more than Rose acknowledges) from the isolation and hostility that she met as a woman scientist in the early twentieth century. From the moment of her appointment as a lecturer in botany at the University of Manchester in 1904, the authorities were "watching her ... carefully", as Rose describes, in some cases hoping for her failure. She became even more exposed when her interests shifted from botany to sex education. Like her contemporary eugenicist Sybil Nevill-Rolfe, a sex educator and campaigner against venereal diseases, her tactics and manners varied from the irritating to the laughable. The unpleasantness of their position as women sex educators at a time of high male anxieties excited all their more unpleasant traits and more extreme tendencies.

Stopes became increasingly crankish and self-infatuated. There is much in this book that makes her seem supremely ridiculous: she was prone to gestures such as sending Hitler a copy of her poems, Love Songs for Young Lovers, or enthusiasms such as making contact with aliens from outer space (she claimed to have seen a flying saucer). Nevertheless she emerges as a magnificent monster, whose achievements were exceptional and enduring. She was a great fool and a great heroine. This is a readable biography of a scientific popularizer who changed the lives of millions and gave good service to her fellow women.

Richard Davenport-Hines is at 51 Elsham Road, London W14 8HD, UK. 